\title{
EFFECT OF DIFFERENT VISUAL IMPAIRMENT LEVELS ON THE QUALITY OF LIFE IN GLAUCOMA PATIENTS
}

\author{
Tina Runjić ${ }^{1}$, Katia Novak Lauš $\check{\check{2}}^{2}$ and Zoran Vatavuk ${ }^{2}$ \\ ${ }^{1}$ Faculty of Education and Rehabilitation Sciences, University of Zagreb, Zagreb, Croatia; \\ ${ }^{2}$ Department of Ophthalmology, Sestre milosrdnice University Hospital Centre, Zagreb, Croatia
}

SUMMARY - The aim of this study was to assess the effect of different visual impairment levels on difference in the subjective quality of life estimation. We included 150 patients with glaucoma whose best-corrected visual acuity in the better-seeing eye was 0.5 and less. All of them were in advanced stage of the disease, with visual field defect worse than $12 \mathrm{~dB}$ in mean defect, when measured with the Octopus Visual Field Analyzer. In order to assess the quality of life, we used the Impact of Vision Impairment questionnaire. Additionally, we used General Information Questionnaire, which was developed for the purpose of this study. The information obtained from the questionnaires was analyzed using the Robust Discriminant Analysis program. Difference analysis was performed for each of the three areas of the questionnaire (reading and accessing information, mobility and independence, and emotional well-being). Results of this study confirmed the difference between the groups of patients with different levels of visual impairment, varying from total visual loss up to visual acuity 0.5 on the better-seeing eye in the effects of visual impairment on the quality of life. All levels of visual impairment had the largest effect in the area of reading and accessing information, slightly less in the area of mobility and independence, and the least effect was in the area of emotional well-being. Based on the results, it is concluded that all levels of visual impairment have negative effect on the quality of life in glaucoma patients.

Key words: Vision Disorders; Quality of Life; Glaucoma; Visual Acuity; Discriminant Analysis; Croatia

\section{Introduction}

Glaucoma is a chronic neurodegenerative disorder of the optic nerve, which causes retinal ganglion cell deterioration and loss of optic nerve axons, leading to structural and functional deficit ${ }^{1}$. Optic nerve damage primarily results in peripheral visual field defect, and in advanced stage also to central visual field loss, loss of fixation ${ }^{2}$, and decrease in visual acuity ${ }^{3}$.

Glaucoma is a progressive disease with symptoms that are difficult to recognize in early stages, thus resulting in impairment of visual functions and irrevers-

Correspondence to: Prof. Tina Runjić, $M D, P h D$, Faculty of Education and Rehabilitation Sciences, University of Zagreb, Borongaj University Campus, Borongajska cesta 83f, HR-10000 Zagreb, Croatia

E-mail: t.runjic@gmail.com

Received December 1, 2015, accepted July 15, 2017 ible blindness ${ }^{4,5}$. Visual impairment has a negative effect on physical activities, economic, social and psychological aspects of life 6 . As a result of visual impairment, patients with glaucoma have problems in orientation and mobility, activities of daily living, accessing information, and in communication. An increased incidence of depression and anxiety was also found in these patients ${ }^{7}$.

According to the research, people with visual impairment consider their visual impairment to have negative effect on their quality of life ${ }^{8-13}$. Quality of life, as defined by the World Health Organization (WHO), is the persons' perception of their position in life in the context of the culture and value systems in which they live and in relation to their goals, expectations, standards and concerns. Quality of life is a multidimensional concept that comprises different aspects of life. The individuals' quality of life has to be esti- 
mated through physical health, material, social and emotional well-being ${ }^{14}$.

Visual field damage, as well as impaired visual acuity affect negatively the performance in most of the activities of daily living and thus decrease the quality of life in glaucoma patients ${ }^{15-18}$. The main quality of life determinant in glaucoma patient is loss of visual functions. Loss of visual functions results in driving problems, trouble in seeing objects in peripheral vision, orientation and mobility problems, night vision problems, light and dark adaptation difficulties, reading and problems in estimating distance, which are the main reasons for the increased number of all-cause falls and serious injuries ${ }^{19,20}$. Although it is commonly considered that these difficulties occur in later stages of the disease, it is apparent that they also occur at the beginning of the disease ${ }^{21-23}$. Along with functional problems, in early stages of the disease, the quality of life is also disrupted by ongoing medication, frequent visits to the doctor, and stressful medical examinations (e.g., perimetry $)^{24-26}$.

In this study, the aim was to assess the effect of different visual impairment levels on the difference in subjective quality of life estimation.

\section{Patients and Methods}

We included 150 glaucoma patients in this study. All of them were patients of the Glaucoma Unit, Department of Ophthalmology, Sestre milosrdnice University Hospital Centre. The best-corrected visual acuity (BCVA) on the better-seeing eye was less than $50 \%$ $(\leq 0.5)$ in all study patients. Most of the patients had near normal vision, 68 of them had visual acuity (VA) of $0.5,15$ patients had visual acuity of 0.4 , and $17 \mathrm{pa}^{-}$ tients had visual acuity of 0.3 . Moderately low vision was found in 14 patients, with visual acuity of 0.2 . Severely low vision was found in 15 patients, with visual acuity of 0.1 , while 21 patients had no visual perception. All of them were in an advanced stage of the disease, which is, according to the European Glaucoma Society (EGS), defined by visual field defect with mean defect (MD) worse than $12 \mathrm{~dB}$, when measured with the Octopus Visual Field Analyzer. The mean age of study patients was 74 years; according to gender, there were $55 \%$ of female and $45 \%$ of male patients.

In order to collect information on the effect of visual impairment on the quality of life, we used the Im- pact of Vision Impairment (IVI) questionnaire ${ }^{27}$, which is a vision-specific quality of life instrument. This questionnaire consists of 28 variables. Answers are scored on a four-point scale: 0 (“a lot”, meaning that visual impairment affects a lot the performance), 1 ("a fair amount"), 2 (“a little"), 3 ("not at all", meaning that visual impairment has no effect on the performance in activity), and 8 ("don't do this for other reasons", meaning that the person cannot perform the activity because of other reasons and not because of vision). The items scored 8 ("don't because of other reasons") were excluded from further analysis. This questionnaire measures the visual impairment effect on the quality of life in three areas: reading and accessing information, mobility and independence, and emotional well-being.

Upon obtaining approval from the appropriate regulatory authorities and ethics committees, verbal consent was obtained from all patients before entering the study.

\section{Results}

Information obtained from the questionnaires was initially processed using discrimination analysis in the robust discriminant analysis program (ROBDIS ${ }^{28,29}$. Differences in discrimination functions relating to visual acuity were tested using Single Factor Analysis of Variance (ANOVA). We confirmed difference among patients according to different visual acuity, varying from total visual loss up to visual acuity 0.5 on the better-seeing eye. Then we performed difference analysis for each of the three areas of the questionnaire (reading and accessing information, mobility and independence, and emotional well-being). Because of the small sample size in each group and because of non-normal distribution of the variables, we used Kruskal-Wallis H test. Results of the robust discriminant analysis in the area of reading and accessing information are presented in Figure 1.

Although we extracted five discriminant functions, only the first one proved significant at the level of $p<0.05$. The position of arithmetic means in the first discriminant function showed that patients with visual acuity of 0.1 estimated their visual impairment to have negative effect on reading and accessing information, much more than patients with other visual acuity values. Moreover, the positive tendency of function in- 
crease implied that better visual acuity had less effect on reading and accessing information. Results of the first discriminant function tended to oscillate in relation to visual acuity from having extremely negative effect in patients with visual acuity of 0.1 with a tendency to decline in the effect across the scale of visual acuity of up to 0.4 . However, the effect was again very negative in patients with visual acuity of 0.5 . Results of the robust discriminant analysis in the area of mobility and independence are presented in Figure 2.

We extracted five discriminant functions in this area too, and the first and second functions were significant at the level of $\mathrm{p}<0.05$. In the area of mobility and independence, graph direction had a negative slope that accompanied the increase in visual acuity. The position of arithmetic means in the first discriminant function showed extremely negative effect of visual impairment in patients with visual acuity of 0.1 and 0.5 . There was a tendency of having less negative results associated with the increase of visual acuity in patients with visual acuity of less than 0.4 .

While analyzing the second discriminant function, we noticed oscillations of the arithmetic means, which were positive in patients with visual acuity of 0.1 and 0.2 , as well as in patients with amaurosis. Furthermore, they were negative in patients with visual acuity between 0.3 and 0.5 . Results of the robust discriminant analysis in the area of emotional well-being are presented in Figure 3.

Statistically significant differences were found only in the second discriminant function, although five of them were extracted. Analysis of the discriminant function graph showed most of the results to be positively oriented, implying that visual acuity had no significant effect on emotional well-being estimation. We also noticed that the arithmetic means in this area were significantly different between the groups of patients only in the second discriminant function. The increase of visual acuity was associated with answers that were more positive and increase of arithmetic mean values, except for patients with visual acuity of 0.4 and amaurosis.

In order to determine differences between the variables describing the effects of visual impairment on the quality of life, we used Kruskal Wallis test. We analyzed each area of the IVI questionnaire in separate. Kruskal Wallis test results of the variables describing the area of reading and accessing information are presented in Table 1 .

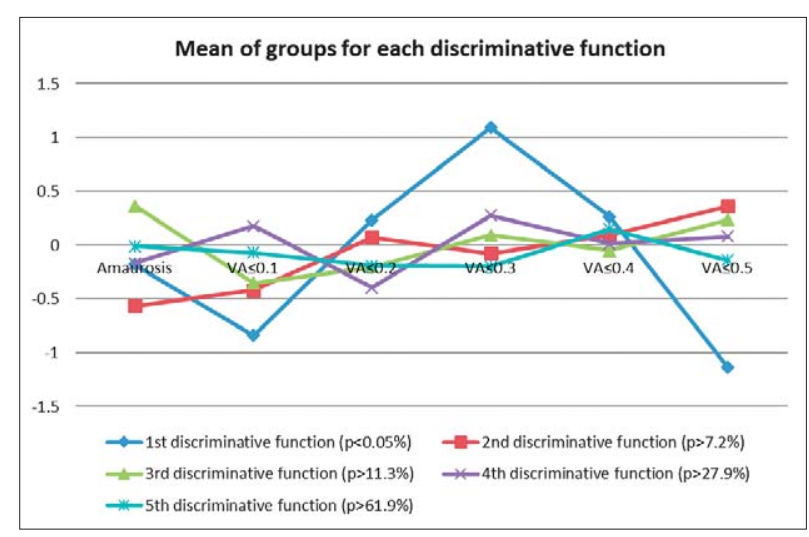

Fig. 1. Results of robust discriminant analysis in the area of reading and accessing information.

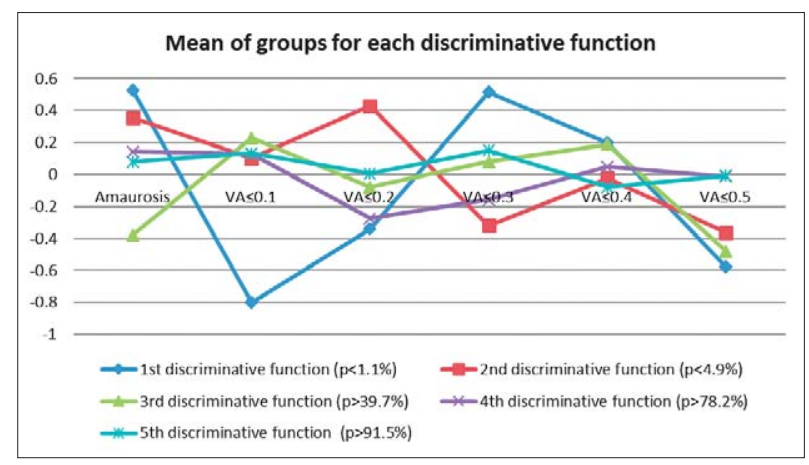

Fig. 2. Results of robust discriminant analysis in the area of mobility and independence.

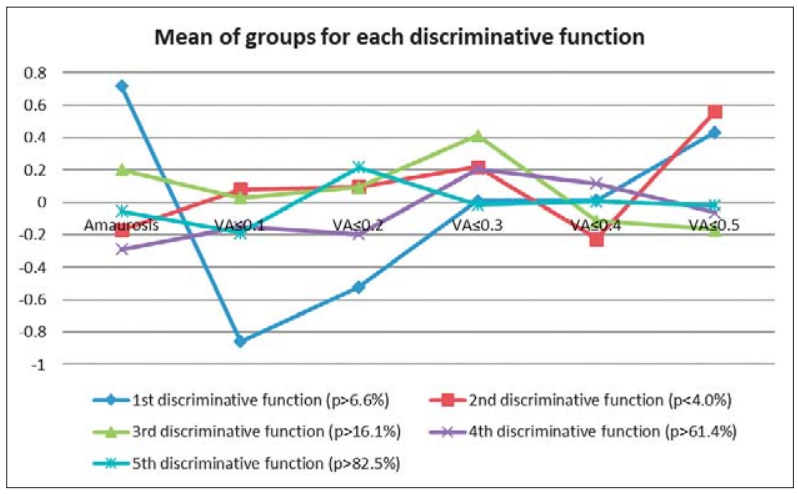

Fig. 3. Results of robust discriminant analysis in the area of emotional well-being.

Statistically significant differences in self-estimated quality of life were found in the IVI 8 (Reading labels or medication instructions) and IVI 14 (Reading black print in standard size - daily newspapers) variables. It is also important to mention that Kruskal 
Table 1. Difference between the groups in the variables of reading and accessing information

\begin{tabular}{|l|l|l|l|l|l|l|l|l|l|}
\hline \multicolumn{10}{|c|}{ Test statistics $\mathrm{a}, \mathrm{b}$} \\
\hline & IVI1 & IVI3 & IVI5 & IVI6 & IVI7 & IVI8 & IVI9 & IVI14 & IVI15 \\
\hline Chi-square & 10.987 & 8.383 & 5.084 & 9.500 & 5.422 & 13.814 & 9.243 & 16.259 & 10.658 \\
\hline Df & 5 & 5 & 5 & 5 & 5 & 5 & 5 & 5 & 5 \\
\hline $\begin{array}{l}\text { Asymp. } \\
\text { Sig. }\end{array}$ & 0.052 & 0.136 & 0.406 & 0.091 & 0.368 & 0.017 & 0.100 & 0.006 & 0.059 \\
\hline
\end{tabular}

aKruskal Wallis test; brouping variable: v.o.

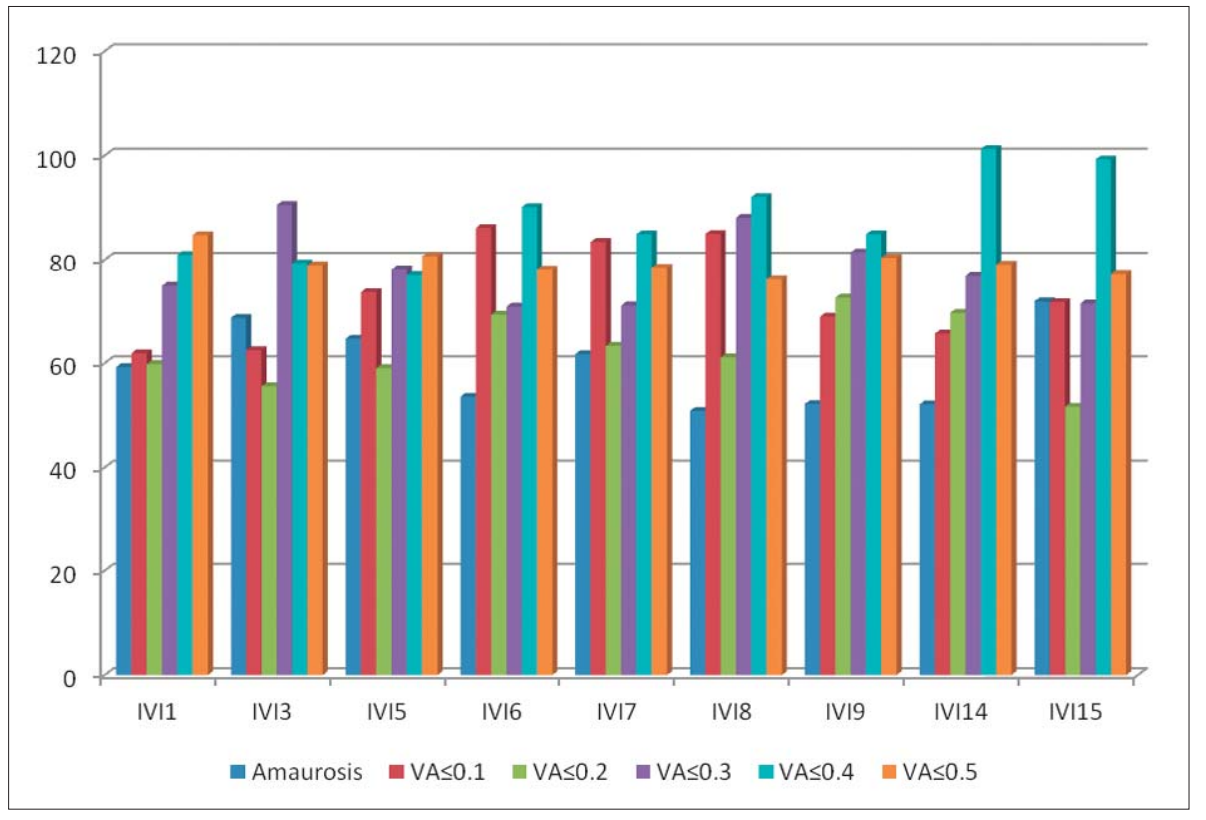

Fig. 4. Medium ranges of results for the area of reading and accessing information.

Table 2. Kruskal Wallis test results for the area of mobility and independence

\begin{tabular}{|l|l|l|l|l|l|l|}
\hline \multicolumn{7}{|c|}{ Test statistics $^{\mathrm{a}, \mathrm{b}}$} \\
\hline & IVI2 & IVI4 & IVI10 & IVI11 & IVI12 & IVI13 \\
\hline Chi-Square & 4.613 & 3.627 & 3.742 & 6.169 & 7.416 & 0.613 \\
\hline df & 5 & 5 & 5 & 5 & 5 & 5 \\
\hline Asymp. Sig. & 0.465 & 0.604 & 0.587 & 0.290 & 0.191 & 0.987 \\
\hline & IVI16 & IVI17 & IVI18 & IVI19 & IVI20 & \\
\hline Chi-Square & 1.726 & 3.341 & 1.296 & 11.002 & 5.331 & \\
\hline df & 5 & 5 & 5 & 5 & 5 & \\
\hline Asymp. Sig. & 0.886 & 0.648 & 0.935 & 0.051 & 0.377 & \\
\hline
\end{tabular}

${ }^{a}$ Kruskal Wallis test; ${ }^{\mathrm{b}}$ grouping variable: v.o.

Wallis test results in the IVI 1 (Your ability of watching and enjoying watching TV) and IVI 15 (Getting requested information) variables were close to the borderline of significance. The medium ranges of the results describing the area of reading and accessing information are presented in Figure 4.
Kruskal Wallis test results of the variables describing the area of mobility and independence are presented in Table 2 .

According to Kruskal Wallis test results presented in Table 2, it was concluded that there was no significant difference in the area of mobility and independence in 
Fig. 5. Medium ranges of the results in the area of mobility and independence.

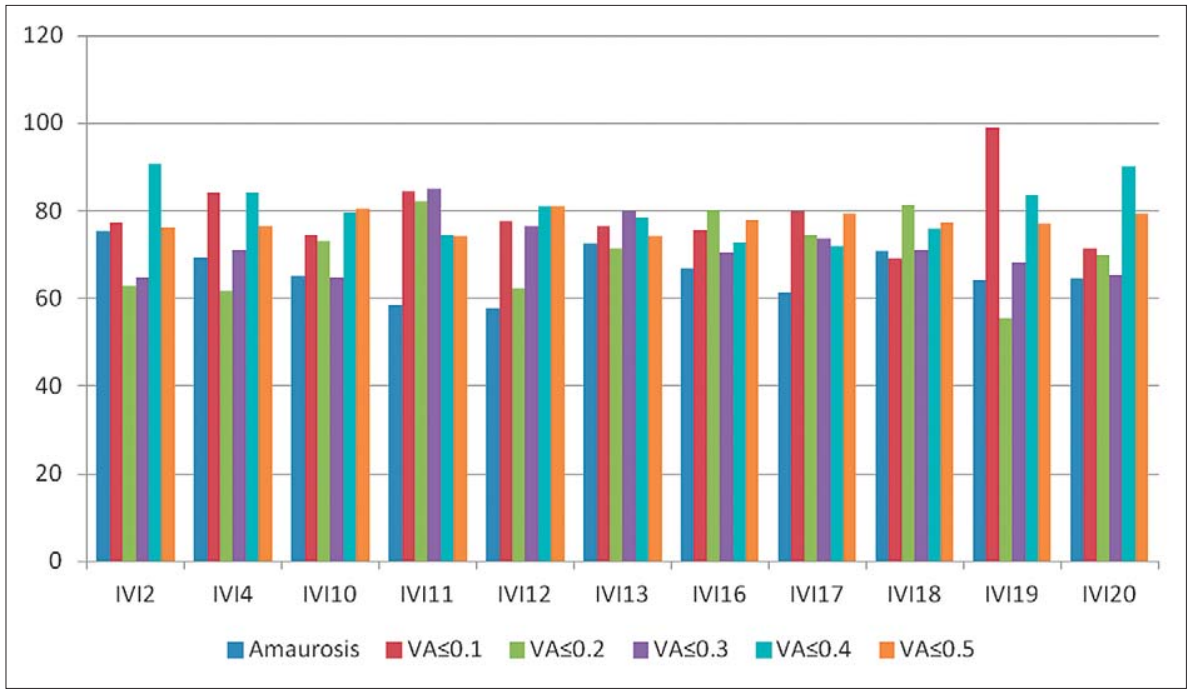

Table 3. Kruskal Wallis test results for the area of the well-being

\begin{tabular}{|l|l|l|l|l|l|l|l|l|}
\hline \multicolumn{8}{|c|}{ Test statistics, $^{\text {a,b }}$} \\
\hline & IVI21 & IVI22 & IVI23 & IVI24 & IVI25 & IVI26 & IVI27 & IVI28 \\
\hline Chi-Square & 3.646 & 6.477 & 2.014 & 5.240 & 11.108 & 3.411 & 3.716 & 6.357 \\
\hline Df & 5 & 5 & 5 & 5 & 5 & 5 & 5 & 5 \\
\hline Asymp. Sig. & 0.601 & 0.263 & 0.847 & 0.387 & 0.049 & 0.637 & 0.591 & 0.273 \\
\hline
\end{tabular}

aKruskal Wallis test; brouping variable: v.o.

Fig. 6. Medium ranges of the results in the area of emotional well-being.

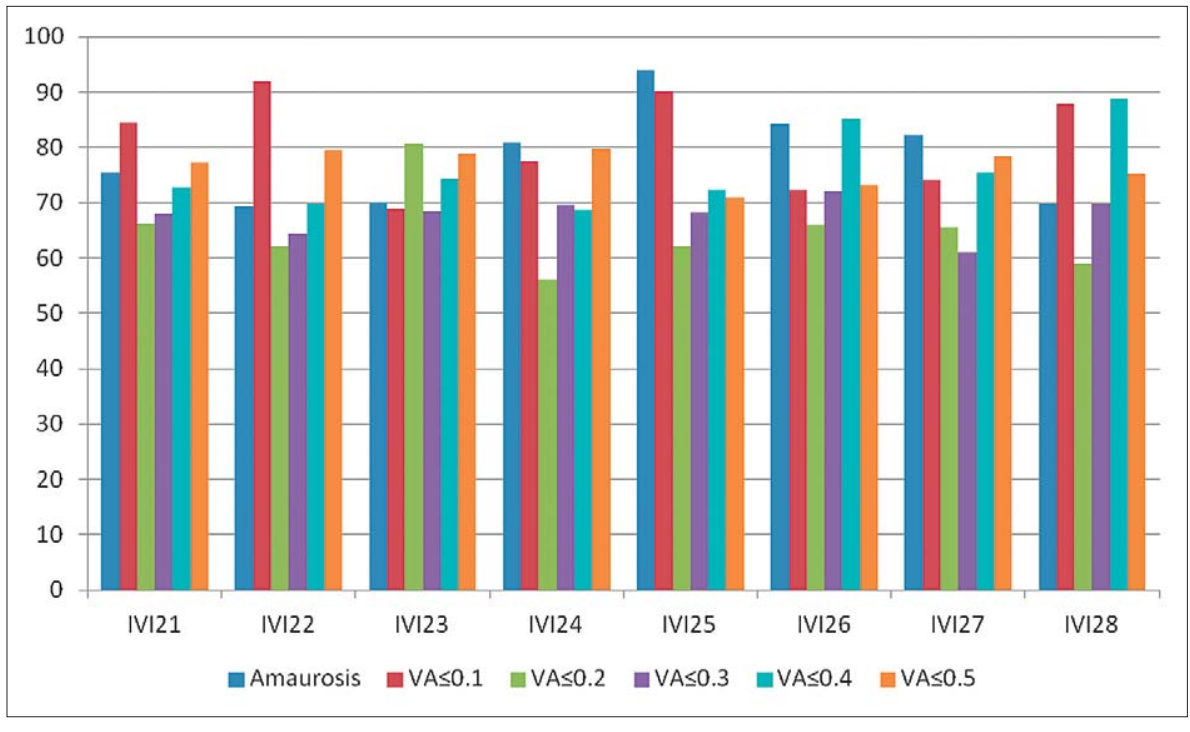

Statistically significant difference was found in the IVI 25 (How often were you concerned about your vision during last month) variable. In other variables describing emotional well-being, significant difference was not found. The medium ranges of the results de- 
scribing the area of emotional well-being are presented in Figure 6.

\section{Discussion}

Results of our study confirmed that visual impairment had a negative effect on the quality of life in glaucoma patients. All levels of visual impairment had the largest effect on the quality of life in the area of reading and accessing information, slightly less in the area of mobility and independence, and the least effect was recorded in the area of emotional well-being. Problems the most patients have in the area of reading and accessing information are related to reading labels and medication instructions. The problem of reading black print standard size, daily newspapers and watching television was also very significant. Based on our results, we conclude that all patients from our study had problems in accessing information, even though these problems were unevenly distributed across the scale of visual acuity. We could assume that objective assessment of the effect of visual impairment on functional abilities in glaucoma patients would give results suggesting that the largest effect of visual impairment is in the area of accessing information, as well as in the activities with black print. Since patients from our study also noticed that visual impairment mostly interrupted these activities, we can assume that reduced availability of information causes significant problems in their lives ${ }^{1}$. Such a finding is easier to comprehend if we consider the need of glaucoma patients for taking medications several times a day. Furthermore, because of advanced age, most of these patients have to take a number of other medications and at the same time they are unable to read the label and the instructions, which can cause serious problems $s^{30,31}$.

In this study, we also confirmed that patients with a higher level of visual impairment had more negative effects on the activities of daily living and mobility ${ }^{3,5}$. We obtained an interesting result related to this negative effect, which indicated that patients with visual acuity of 0.4 and 0.5 experienced more problems in this area than patients with lower visual acuity values. We can assume that this result was related to the level of daily activities in those patients. Patients with higher visual acuity values tend to stay more active, therefore they experience more problems than patients with lower visual acuity values, who become less active.
Emotional well-being in glaucoma patients is generally connected with visual impairment ${ }^{3,7,8,13,25}$, although different degrees of vision loss are not related to self-estimation of emotional state.

This study confirmed that visual impairment had a negative effect on the quality of life in glaucoma patients $^{1-17}$. Nevertheless, disparities of results related to different levels of visual impairment indicate the need for further research. By expanding this research with inclusion of the objective functional assessment tests along with the subjective quality of life tests used, we would be able to provide better description of the effects that visual impairment has on the quality of life in glaucoma patients.

\section{References}

1. Waisbourd M, Parker S, Ekici F, Martinez P, Murphy R, Scully $\mathrm{K}$, et al. A prospective, longitudinal, observational cohort study examining how glaucoma affects quality of life and visuallyrelated function over 4 years: design and methodology. BMC Ophthalmol. 2015 Aug 1;15:91. doi: 10.1186/s 12886-0150088-x.

2. Jampel HD. Glaucoma patients' assessment of their visual function and quality of life. Trans Am Ophthalmol Soc. 2001;99;301-17.

3. Chan WE, Chiang PCP, Liao J, Rees G, Wong YT, Larn SHJ, et al. Glaucoma and associated visual acuity and field loss significantly affect glaucoma-specific psychosocial functioning. Ophthalmology. 2015 Mar;122(3):494-501. doi: http://dx.doi. org/10.1016/j.ophta.2014.09.030.

4. Severn P, Fraser S, Finch T, May C. Which quality of life score is best for glaucoma patients and why? BMC Ophthalmol. 2008 Jan 23;8:2. doi: 10.1186/1471-2415-8-2.

5. Prado Vega R, van Leeuwen PM, Rendon Velez E, Lemij HG, de Winter JC. Obstacle avoidance, visual detection performance, and eye-scanning behavior of glaucoma patients in a driving simulator: a preliminary study. PloS One. 2013 Oct 16;8(10):e77294. doi: 10.1371/journal.pone.0077294. eCollection 2013.

6. Silverstone B, What does vision impairment mean to older people? In: Wahl HW, Shulze HE, editors. The special needs of blind and low vision seniors; research and practice concept. IOS Press; 2001: p. 3-11.

7. Kong XM, Zhu WQ, Hong JX, Sun XH. Is glaucoma comprehension associated with psychological disturbance and visionrelated quality of life for patients with glaucoma? A cross-sectional study. BMJ Open. 2014 May 26;4(5):e00462. doi: 10.1136/bmjopen-2013-004632.

8. Kempen GI, Ballemans J, Ranchor AV, van Rens GH, Zijlstra GA. The impact of low vision on activities of daily living, symp- 
toms of depression, feelings of anxiety and social support in community-living older adults seeking vision rehabilitation services. Qual Life Res. 2012 Oct 21;8:1413. doi: 10.1007/ s11136-011-0061-y.

9. Langelaan M, de Boer MR, van Nispen RM, Wouters B, Moll $A C$, van Rens GH. Impact of visual impairment on quality of life: a comparison with quality in the general population and with other chronic conditions. Ophthalmic Epidemiol. 2007 May/Jun;14(3):119-26.

10. Langelaan M, de Boer MR, van Nispen RM, Wouters B, Moll $A C$, van Rens GH. Change in quality of life after rehabilitation: prognostic factors for visually impaired adults. Int J Rehabil Res. 2009 Mar;32(1):12-9. doi: 10.1097/MRR.0b013e3283063503.

11. Broman AT, Munoz B, Rodriguez J, Sanchez R, Quigley HA, Klein $\mathrm{R}$, et al. The impact of visual impairment and eye disease on vision-related quality of life in a Mexican-American population: project VER. Invest Ophthalmol Vis Sci. 2002 Nov; 43(11):3393-8.

12. Finger RP, Fenwick E, Marella M, Dirani M, Holz FG, Chiang PP, et al. The impact of vision impairment on vision-specific quality of life in Germany. Invest Ophthalmol Vis Sci. 2011 Jun 1;52(6):3613-9. doi: 10.1167/iovs.10-7127.

13. Nyman SR, Gosney MA, Victor CR. Psychosocial impact of visual impairment in working-age adults. $\mathrm{Br} \mathrm{J}$ Ophthalmol. 2010 Nov 94;(11):1427-31. doi: 10.1136/bjo2009.164814.

14. Vuletić G, Misajon RA. Subjektivna kvaliteta života. In; Vuletić G, editor. Kvaliteta života i zdravlje. Osijek: Sveučilište Josipa Jurja Strosmayera, 2011; p. 9-16. (in Croatian)

15. Parish RK, Gedde SJ, Scott IU, Feuer WJ, Schiffman JC, Mangione CM, et al. Visual function and quality of life among patients with glaucoma. Arch Ophthalmol. 1997 Nov;115 (11):1447-55 .

16. Cypel MC, Kasahara N, Atique D, Umbelino CC, Alcantara MP, Seixas FS, et al. Quality of life in patients with glaucoma who live in a developing country. Int Ophthalmol. 2004 OctDec;25(5-6):267-72.

17. Gutierrez P, Wilson MR, Johnson C, Gordon M, Coffi GA, Rich $\mathrm{R}$, et al. Influence of glaucomatous visual field loss on health-related quality of life. Arch Ophthalmol. 1997 Jun; 115(6):777-84.

18. Onakoya AO, Mbdaugha CA, Aribaba OT, Ibidapo OO. Quality of life of primary open angle glaucoma patients in Lagos, Nigeria: clinical and sociodemographic correlates. J Glaucoma. 2012 Jun-Jul;21(5):287-95. doi: 10.1097/IJG.0b013e31820d7cfd.

19. Hagman J. Comparison of resource utilization in the treatment of open-angle glaucoma between two cities in Finland: is more better? Acta Ophthalmol. 2013 May; 91 Thesis 3:1-47. doi: 10.1111/aos.12141.

20. Skalicky S, Goldberg I. Quality of life in glaucoma patient. U S Ophthalmic Rev. 2013;6(1):6-9. doi: http://doi.org/10.17925/ USOR.2013.06.01.6.

21. Crabb DP. When a defect becomes a disability. Ophthalmol Manag. 2012 Feb;16:32-5.

22. Spaeth G, Walt J, Keener J. Evaluation of quality of life for patients with glaucoma. Am J Ophthalmol. 2006 Jan;141 (1 Suppl):3-14.

23. Ramulu P. Glaucoma and disability: which tasks are affected, and what stage of disease? Curr Opin Ophthalmol. 2009 Mar;20(2):92-8. doi: 10.1097/ICU.0b013e32832401a9.

24. Christoph H, Reznicek L, Vogel M, Pesudovs K. The impact of structural and functional parameters in glaucoma patients on patient-reported visual functioning. PloS J [updated 2013 Dec 3]. Available from: http://dx.doi.org/10.1371/journal.pone0080757.

25. Jampel HD, Frick KD, Janz NK, Wren PA, Musch DC, Rimal $\mathrm{R}$, et al. Depression and mood indicators in newly diagnosed glaucoma patient. Am J Ophthalmol. 2007 Aug;144:238-44.

26. Janz NK, Wren PA, Lichter PR, Musch DC, Gillespie BW, Guire BW et al. The collaborative initial glaucoma treatment study: interim quality of life findings after initial medical or surgical treatment of glaucoma. Ophthalmology. 2001 Nov; 108(11):1954-65.

27. Weih LM, Hassell JB, Keeffe J. Assessment of the impact of vision impairment. Invest Ophthalmol Vis Sci. 2002 Apr;43 (4):927-35.

28. Nikolić B. Neki modeli za rješavanje problema planiranja i kontrole transformacijskih procesa u primjeni kompjutora kod osoba s teškoćama socijalne integracije. Defektologija. 1991;28 (1):129-39. (in Croatian)

29. Štalec J, Momirović K. On a very simple method for robust discriminant analysis. Proceedings of the $6^{\text {th }}$ International Symposium Computer at the University, Dubrovnik, 1984; 512.1-515.16.

30. Spratt A, Kotecha A, Viswanathan A. Quality of life in glaucoma. J Curr Glaucoma Pract. 2008 Jan-Apr;2(1):39-45.

31. Nordmann JP, Auzanneau N, Ricard S, Berdeaux G. Vision related quality of life and topical glaucoma treatment side effects. Health Qual Life Outcomes. 2003 Dec 10;1:75.

32. McKean-Cowdin R, Wang Y,Wu J, Azen SP, Varma R. Impact of visual field loss on health-related quality of life in glaucoma; the Los Angeles Latino Eye Study. Ophthalmology. 2008 Jun; 115(6):94. 


\section{Sažetak}

\section{UTJECAJ OŠTEĆENJA VIDA NA KVALITETU ŽIVOTA BOLESNIKA S GLAUKOMOM}

\section{T. Runjič, K. Novak Lauš i Z. Vatavuk}

Cilj istraživanja bio je utvrditi utjecaj oštećenja vida na kvalitetu života bolesnika s glaukomom. Istraživanjem je obuhvaćeno 150 bolesnika s glaukomom, s ostatkom vida od 50\% i manje na boljem oku (vidna oštrina $\leq 0,5$ ). Svi su bili u terminalnoj fazi bolesti, s oštećenjem vidnoga polja većim od $12 \mathrm{~dB}$ u Mean Defects (MD) mjerenim analizatorom vidnog polja Octopus. Za mjerenje utjecaja oštećenja vida na kvalitetu života primijenjen je upitnik The Impact of Vision Impairment (IVI), a dodatno je primijenjen upitnik vlastite izrade General Information Questionnaire. Prikupljeni podaci su obrađeni modelom robustne diskriminacijske analize (ROBDIS). Utvrđena je razlika između skupina ispitanika s različitim stupnjem oštećenja vida, od potpunog gubitka vida do ostatka vida na boljem oku od 50\%. Za svako od tri područja (čitanje i pristup informacijama, kretanje i samostalnost te emocionalno blagostanje) učinjena je razlikovna analiza. Rezultati istraživanja potvrdili su da oštećenje vida utječe na kvalitetu života bolesnika s glaukomom. Najveći utjecaj različitih stupnjeva oštećenja vida bio je očit u području čitanja i pristupa informacijama, nešto manji u području orijentacije i kretanja, a najmanji u području emocionalnog blagostanja.

Ključne riječi: vidne smetnje; kvaliteta života; glaukom; vidna oštrina; diskriminantna analiza; Hrvatska 